\title{
Relasi Makna Orang Kafir dan Muttaqîn dalam Islam
}

\author{
Sihabussalam \\ UIN Syarif Hidayatullah Jakarta \\ sihabussalam471@gmail.com
}

\begin{abstract}
This paper will explain the relation of eating infidels and pious people in Islam. This research is a qualitative research using Charles Sanders Pierce's semiotic approach. The data used in this paper is sourced from books, journals, and also other literature that is relevant to the theme of the writing.
\end{abstract}

Kata Kunci: Kafir, Muttaqîn, Semiotic

\section{Pendahuluan}

Turunnya al-Qur'an tidak terlepas dari waktu, audiens, dan tempat. Tiga unsur tersebut disamping menjadi perdebatan dan diskursus penetapan makiyah dan madaniyah, sekaligus menjadi landasan interpretasi bagi para pengkaji al-Qur'an. Bahkan bagi fuqaha sangat urgen sebagai penetapan hukum yang diambil dari konsep naskh mansukh. Kedatangan al-Qur'an pada masa itu melahirkan respon yang bervariasi dari audiens masyarakat, khususnya kota Mekah dan Madinah. Kota Mekah yang menjadi tempat kelahiran Nabi Muhammad menjadi sasaran awal setelah Nabi mendapatkan wahyu pertama. Bersamaan dengan itu, secara otomatis medan dakwah Rasulallah dimulai. Keadaan masyarakat pada saat itu ada dalam kemusyrikan dan tidak bertauhid kepada Allah swt, visi dan misi Rasulullah pada saat itu terfokus pada pemberatasan kemusyrikan dan pemantapan meng-Esakan kepada Allah swt. Selama 10 tahun berliau membagun landasan dan asas ketauhidan di masyarakat Mekah. Namun, perjalanan dakwah beliau tidak selamanya menemui kenikmatan dan kelancaran, sehingga pada akhirnya beliau hijrah ke Madinah.

Dalam menghadapi masyarakat Madinah, Nabi memiliki strategi yang berbeda pada saat berada di Mekah. Kondisi masyarakat Madinah dengan Mekah memiliki perbedaan, walaupun Nabi belum menetap di tanah Madinah, banyak masyarakatnya 
sudah mengetahui dan mengimani Allah dan Nabi-Nya. Keadaan tersebut dapat dilihat dari resepsi Nabi dengan masyarakat Madinag yang disambut hangat oleh sahabat Anshar. Disamping faktor akidah yang membedakan, sosio-kultural yang beraneka ragam menjadi faktor tambahan. Dengan berbagai keanekaragaman tersebut perlu adanya konstitusi yang mengatur seluruh masyarakat, maka dibuatlah konstitusi Madinah. Sebuah perjanjian atau peraturan yang mengedepankan keberagaman dan memerhatikan hak dan kewajiban setiap golongan demi berlangsungnya negara madani.

Kompleksitas masyarakat saat itu, tentunya harus ada ketegasan dan kategorisasi mana yang termasuk mukmin, kafir, dan munafik. Dengan menunjukkan ciri-ciri masing-masing dari tiga drajat tersebut diharapkan masyarakat tidak salah menempatkan dirinya, supaya apa yang dicita-citakan Nabi dan Islam terealisasi. Kategorisasi tersebut dapat kita jumpai pada permualaan surat al-Baqarah. Diawali dengan menyebutkan ciri-ciri orang yang bertaqwa dengan didesain dengan keimanan kepada hal yang gaib, kitab-kitab Allah, dan menjalankan salat sebagai realisasi keimanan serta memiliki simpati, empati, dan kesadaran sosial yang digambarkan oleh pendistribusian harta dijalan Allah, baik berupa sedekah atau zakat. Gambaran tersebut terdapat pada ayat 2-5; pada ayat 5 tersebut merupakan reward bagi mereka yang mampu menguasai apa yang telah disebutkan pada ayat sebelumnya.

Kemudian, pada ayat selanjutnya (6 dan 7) Allah secara tegas menunjukan orang kafir dengan kalimat inna al-ladzina kafaru. Walaupun Allah menyebutkan tujuan ayat tersebut dengan tegas, tetapi ciri-ciri dari mereka disebutkan secara implisit, tidak secara eksplisit sebagaiamana Allah menyifati orang-orang mukmin. Kendati demikian, perlu adanya interpretasi untuk memberikan pemahaman yang komprehensif. Oleh sebab itu, dalam tulisan ini akan memberikan pemahaman yang menyegarkan terkait relasi interpretasi dari kedua kubu tersebut dengan melihat tanda-tanda yang terkandung di dalam ayat tersebut. Rumusan masalah pada tulisan ini adalah bagaimana makna yang terkandung dalam surat al-Baqarah ayat 6-7 yang diindikasikan sebagai ciri orang kaafir?

Salah satu pendekatan sebagai cara untuk menyelesaikan permasalah di atas adalah dengan menggunakan pendekatan semiotika. Salah satu penggagas semiotika adalah Charles Sanders Pierce -selanjutnya Pierce-. Ia mengatakan bahwa tanda-tanda berkaitan dengan objek-objek yang menyerupainya, keberadaannya memiliki hubungan 
kausal dengan tanda-tanda atau ikatan konvesional dengan tanda-tanda tersebut. ${ }^{1}$ Bagi Pierce tanda adalah yang mewakili sesuatu bagi seseorang. Tanda itu sendiri merupakan contoh dari keperteamaan dan objeknya adalah kekeduaan, dan penafsiranya adalah orang keketigaan. ${ }^{2}$

Tulisan ini menggunakan metode kualitatif-interpretatif yaitu sebuah metode penelitian yang memfokuskan objek kajiannya pada tanda dan teks. Serta dengan pendekatan semiotika ala Pierce yaitu pembacaan interpretasi serta hubungan kausalitas antara ground (repsentemen), object, dan interpretation.

\section{Teori Semiotika Charles Sanders Pierce}

Perkembangan disiplin ilmu semiotika tidak akan terlepas dari dua arus besar yaitu perkembangan yang terjadi di Eropa dan Amerika Serikat. Saussure menjadi pionir ditanah Eropa dan Pierce ditanag Amerika Serikat. Kedua tokoh tersebut melahirkan sumbangsih ilmu pengetahuan yang sangat baik, walaupun dari dua belakang yang berbeda, Saussure dari linguistik dengan mengembangkan semiologi dan Pierce dari filsafat yang mengembangkan semiotic. Namun, dapat ditarik persamaan bahwa semiotika tidak hanya berbicara bahasa dan filsafat, lebih dari itu semiotika diartikan sebagai tanda yang ada dalam kehidupan masyarakat baik sosial, budaya, dan seni.

Pierce lahir pada tanggal 10 September 1839 di Cambridge, Massachusetts, Amerika Serikat. Perjalanan inteletualnya diawali di Univershun beitas Harvard dengan jenjang pendidikan sarjananya diselesaikan pada tahun 1859, gelar masternya diraih pada tahun 1962 dan di tahun berikutnya mendapat gelar B.sc (Bachelors of Science) pada bidang kimia dengan nilai cumlaude. Pierce dikenal sebagai seorang filosofis Amerika yang juga dikenal sebagai ahli logika dengan pemahamannya terhadap manusia dan penalran (ilmu pasti). Logika yang mengakar pada manusia ketika berfikir melibatkan tanda sebagai keyakinan manusia. Ia mengatakan manusia berfikir dalam tanda, yang menjadi unsur komunikasi. Bagi Pierce tanda tidaklah sebagai suatu

\footnotetext{
${ }^{1}$ Arthur Asa Berger, Semiotika; Tanda-tanda dalam Kebudayaan Kontemporer (Jakarta: Tiara Wacana, 2010), 244. Dalam Wahyu Hanafi, "Semiotika Al-Qur'an: Representasi Makna Verba Reflektif Perilaku Manusia dalam Surat Al-Ma'un dan Bias Sosial Keaagamaan”. Jurnal Dialogia, Vol. 15, No. 1, (Juni 2017), 3.

${ }^{2}$ Wahyu Hanafi, "Semiotika Al-Qur'an: Representasi Makna Verba Reflektif Perilaku Manusia dalam Surat Al-Ma'un dan Bias Sosial Keaagamaan”, 3.
} 
struktur, tetapi proses pemaknaan yang dilakukan dengan tiga tahap, ${ }^{3}$ yakni representamen, objek, dan interpretan.

Berdasarkan representamen, Pierce mengatakan bahwa konsekuensi dari tanda itu harus difungsikan dalam istilahnya ground, adalah tanda (sign atau representamen) selalu terdapat dalam hubungan triadik, yaitu ground, object, dan interpretant. Ia mengklasifikasi tanda menjadi tiga bagian: pertama, qualisign, yaitu kualitas yang ada dalam tanda dan lebih pada keadaan sifatnya, misalnya keras, kasar, lembut, suka, duka, lemah, merdu, warna hitam, putih; Kedua, sinsign, eksistensi aktual benda atau peristiwa yang ada pada tanda (tanda atas dasar kejadian yang sedang terjadi atau kenyataan, misalnya "besi yang berkarat" menandakan besi tersebut tidak tahan air dan cuaca, kata "keruh" pada kalimat sungai itu keruh, yang menandakan bahwa ada hujan di hulu sungai; Ketiga, legisign yaitu norma yang dikandung oleh tanda, misalnya rambu-rambu lalu lintas, yang menandakan hal-hal yang boleh atau tidak boleh dilakukan oleh manusia. ${ }^{4}$

Berdasarkan objeknya, Pierce membagi tanda atas icon (ikon), index (indeks), dan symbol (simbol). ${ }^{5}$ Ia menggunakan ikon untuk kesamaan, indeks untuk hubungan kausalitas, dan simbol untuk asosiasi konvesionalnya. ${ }^{6}$ Dalam terminologinya, indeks adalah tanda yang berhubungan antara penanda di dalamnya bersifat kausal. Ikon adalah tanda yang berhubungan antara penanda dan petandanya bersifat keserupaan. Sedangkan simbol adalah tanda yang hubungan antara penanda dan petandanya bersifat arbiter. $^{7}$ Sebagai contoh kemiripan foto dengan orangnya untuk ikon. Mendung menandakan akan hujan utuk indeks. Lambang garuda pancasila, lambang Salib untuk agama Kristen untuk simbol.

${ }^{3}$ Alifatul Qolbi Mu'arrofah, Representasi Masyarakat Pesisir: Analisis Semiotika dalam Novel Gadis Pesisir Karya Nunuk Y. Kusmiana. "Kajian Linguistik pada Karya Sastra". Prosiding seminar Nasional Linguistiks dan Sastra (SEMANTIKS) 2019. http://jurnal.uns.ac.id/semantiks, 73.

${ }^{4}$ Wahyu Hanafi, "Semiotika Al-Qur'an: Representasi Makna Verba Reflektif Perilaku Manusia dalam Surat Al-Ma'un dan Bias Sosial Keaagamaan", 9 dari buku Alex Sobur, Semiotika Komunikasi (Bandung: PT. Remaja Rodakarya, 2013), 41.

5 Wahyu Hanafi, "Semiotika Al-Qur'an: Representasi Makna Verba Reflektif Perilaku Manusia dalam Surat Al-Ma'un dan Bias Sosial Keaagamaan", 9 dari buku Alex Sobur, Semiotika Komunikasi (Bandung: PT. Remaja Rodakarya, 2013), 41.

6 Wahyu Hanafi, "Semiotika Al-Qur'an: Representasi Makna Verba Reflektif Perilaku Manusia dalam Surat Al-Ma'un dan Bias Sosial Keaagamaan", 9 dari buku Alex Sobur, Semiotika Komunikasi (Bandung: PT. Remaja Rodakarya, 2013), 41.

7 Wahyu Hanafi, "Semiotika Al-Qur'an: Representasi Makna Verba Reflektif Perilaku Manusia dalam Surat Al-Ma'un dan Bias Sosial Keaagamaan", 9 dari buku Alex Sobur, Semiotika Komunikasi (Bandung: PT. Remaja Rodakarya, 2013), 41. 
Adapun kontruksi semiotika al-Qur'an sebagaimana yang dikemukakan oleh Wahyu Hanafi dalam jurnalnya, ${ }^{8}$ bahwa dalam implementasi semiotika al-Qur'an tidak hanya merepresentasikan makna dalam tanda-tanda (ayat-ayat al-Qur'an), akan tetapi lebih dalam mendialogkan tanda-tanda tersebut ke dalam wacan yang seharusnya, sehingga bisa membentuk repsentasi makna yang baru. Pada analisis tipologi tanda berikutnya adalah dengan mengkobinasikan tiga unsur segitiga triadik. Kemudian, analisis tipologi tanda (indeks, ikon, dan simbol) merupakan satuan ground yang dalam al-Qur'an adalah satuan dasar terkecil yang disebut dengan ayat. manifestasi ayat-ayat tersebut merupkan penanda (signifier) yang menjadi objek pembahasan. Kemudian, posisi objek (signified) merupakan objek yang akan dijadikan acuan terhadap ground yang meliputi fenomena-fenomena yang tepat dalam bahasan dengan menyesuaikan konteks ayat-ayat al-Qur'an. Selanjutnya, pada posisi terkhir adalah interpretantny uyakni dimana pembaca mampu memberikan representasi tingkat pertama dan dikembangkan pada repsentasi tingkat kedua, ketiga, dan seterusnya sehingga membentuk makna dialogis. Sistem kerja tanda semiotika al-Qur'an ini dirasa lebih efektif dalam mendialogkan antara wacana tekstual dengan fenomena kontekstual. Model analisis tanda semacam ini merupakan model analisis tanda interpretatif tingkat individual. Unsur pokok dalam analisis kerja antara penanda dan petanda semcam ini secara tidak langsung akan membuahkan makna konotasi yang terus berkembangan dan menjadi makna denotasi secara final tergantung posisi pembaca teks.

\section{Relasi Interpretasi Makna Q.S al-Baqarah ayat 2-7}

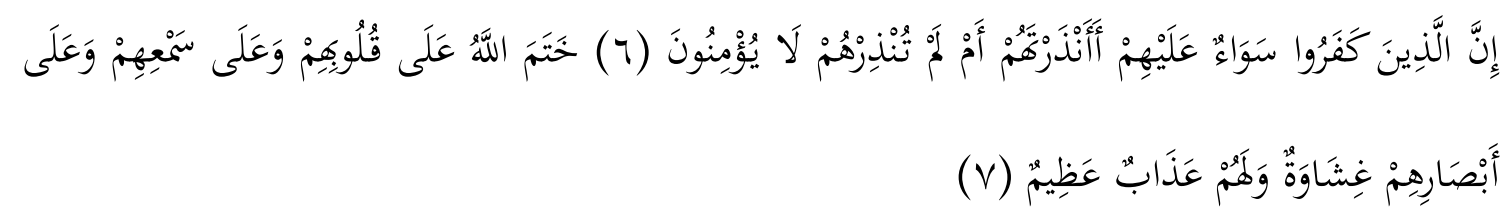

"Sesungguhnya orang-orang kafir sama saja bagi mereka apakaha mereka diberi peringatan atau tidak diberi peringatan, mereka tidak juga akan beriman. Allah mengunci mata hati mereka, begitupun

\footnotetext{
8 Wahyu Hanafi, "Semiotika Al-Qur'an: Representasi Makna Verba Reflektif Perilaku Manusia dalam Surat Al-Ma’un dan Bias Sosial Keaagamaan”. Jurnal Dialogia, Vol. 15, No. 1, (Juni 2017), 3.

${ }^{8}$ Wahyu Hanafi, "Semiotika Al-Qur'an: Representasi Makna Verba Reflektif Perilaku Manusia dalam Surat Al-Ma’un dan Bias Sosial Keaagamaan” 15.
} 
pendengaran mereka, sedengkan penglihatan mereka ditutup dan bagi mereka siksa yang besar".

Dalam permulaan surat al-Baqarah, Allah mempertegas eksistensi kitab al-Qur'an dengan ungkapan laa Raiba fihi "tidak ada keraguan di dalamya" dan fungsi darinya yaitu sebagai petujuk bagi orang takwa. Orang-orang takwa disifati dari ayat 3 dan 4, kemudian pada ayat 5 disebutkan balasan bagi mereka. Pada ayat selanjutnya yakni 6 dan 7 Allah menceritkan orang-orang kafir. Tidaknya disebutkan secara rinci ciri-ciri orang kafir dan hal itu menunjukan esensi Tuhan bahwa orang kafir tidak akan menerima kebenaran yang datang dari-Nya baik sebelum atau sesudah ada peringatan. Namun, ciri-ciri tersebut dapat ditemukan dengan menggunakan interpretant dari teori semiotika Pierce.

Di dalam ayat 6 diawali dengan kata "inna" yang memiliki pengertian "sesungguhnya". Secara semiotis, kata -huruf dalam bahasa Arab- tersebut menunjukan penanda (ground/representament sinsign) yang berdasarkan hal yang pasti dan benar terjadi atau kenyataan. Kata inna memberikan makna "sesungguhnya" (ground). Representasi makna "sesungguhnya" akan melahirkan petanda (objek simbol) sesuatu yang sebenarnya, dalam konteks ini sifat orang kafir. Ground melahirkan petanda (objek) tingkat pertama yaitu sikap yang menunujukan penggunaan kata inna, terma tersebut membentuk representasi pada tingkatan kedua yaitu kebenaran atas kejadian tersebut, dalam konteks ini ini mengingkari kebenaran. Kemudian, representasi tersebut membuahkan bahwa penggunaan inna disana adalah bentuk kebenaran dalam menyekutukan Allah dan tidak mau menerima hal-hal yang benar.

Pada kalimat kafarû merupakan repsentamen/tanda yang memberikan makna "menutupi atau tertutupnya sesuatu". Repsentasi makna "menutupi atau tertutupnya sesuatu" melahirkan petanda (objek) sesuatu yang ditutupi baik secara sempit atau secara luas, dalam hal ini kafir keluar dari agama Islam. Ground (penanda) melahirkan petanda tingkat pertama yaitu sikap atau prilaku yang menunjukan ketertutupan, kemudian term tersebut melahirkan dan menjadikan representasi (objek) tingkat kedua yaitu sebab terjadinya sikap atau perilaku yang mendorong mereka melakukan perbuatan kafir, seperti memilki sikap sombong, tidak percaya kepada hal yang gaib. Kemudian, representasi (objek) tingkat ketiga yaitu ditunjukan oleh sikap kafir mereka, seperti menyembah berhala, uang, jabatan, dan dunia. Dari proses semiosis tersebut 
dapat dipahami bahwa kekafiran yang mereka lakukan bukan pada ranah kufur nikmat, tetapi kekafiran atau menutup diri dari hal-hal yang benar yang datang dari Allah dan Nabi karena kesombongan mereka dan tidak percayaanya mereka pada hal yang gaib. Kemudian realisasi dan bentuk asli dari tidak percaya mereka adalah menyembah/menuhankan berhala (patung), uang, jabatan, dan dunia sehingga ia lupa kepada dzat yang harus dituhankan yaitu Allah.

Kemudian, apabila kafarû merupakan repsentamen/tanda yang memberikan makna "antonim dari iman" dengan proses semiosis sama seperti yang di atas, maka interpretasi ayat tersebut sudah mencakup ciri dari sikap orang kafir, yaitu (1) tidak mempercai/tidak beriman terhadap sesuatu yang telah diturunkan oleh Allah -al-Qur'an, Taurat, Zabur, dan Injil-; (2) tidak yakin adanya hari akhir; (3) tidak percaya pada hal yang gaib -seperti hari kebangkitan, surga, dan neraka-; (4) tidak melaksanakan salat dengan menghinkannya-; (5) tidak mendistribusikan harta di jalan Allah atau tidak menunaikan hak dari harta tersebut.

Pada kata mَّor merupakan kontruksi ism masdar yang mempunyai makna fail subjek-. Kata tersebut memiliki arti "sama atau menyamakan" yang menjadi representamen/tanda. Kemudian penanda/tanda tersebut (ground/ representamen) berhubungan dengan objek "orang kafir" maka membuahkan interpretan "Allah menyakamakan mereka". Kemudian menjadi representamen kedua yaitu mereka menilai dan menyikapi peringatan dari Allah dengan sama. Dan pada repsentament ketiga adalah setelah mereka mendapatkan peringatan, mereka tetap dalam kekafiran. Dengan demikian, interpretasi dari relasi makna tersebut adalah Allah menyamakan mereka -orang kafir- karena mereka tidak diberi peringatan atau bahkan setelah diberikan peringatan, tetap tidak beriman dan ada dalam kemuysrikan.

Pada ayat selanjutnya, Allah memebrikan konsekuensi kepada mereka karena masih tidak beriman ${ }^{9}$ yaitu Allah mengunci mata hati mereka, begitupun pendengaran mereka, sedengkan penglihatan mereka ditutup dan bagi mereka siksa yang besar. Term khatama yang memiliki "mengunci" derivasi tersebut sinonim dari kata katama "menyembunyikan" yang pada tahapan ini disebut dengan penanda (ground). Petanda (objek) pertama dari kontruksi dan redaksi ayat adalah mengunci hati dan pendengaran.

\footnotetext{
${ }^{9}$ Fakhruddin Ar-Razi, Mafatih al-Ghaib, jilid. 2, cet. 3 (Beirut: Dar Ihya al-Turats al-‘Arabi, 1429
} H), 291. 
Kemudian representasi (objek) kedua adalah dengan tidak memberikan petunjuk atau ketenagan dalam hati dan tidak diberikan pendengaran terhadap hal yang baik. Adapun representasi (objek) pada tingkat ketiga adalah disebabkan hati mereka tidak yakin dan pendengarannya tidak diperdengarkan pada risalah yang telah ada pada diri Nabi. Repsentasi demikian meberikan makna bahwa Allah mengunci hati dan pendengaran mereka karena perilaku mereka yang tidak mengimani dengan hati dan mereka abai terhadap apa yang yang telah dibawa oleh nabi, dengan tidak mendengarkannya. Oleh sebab itu, bentuk dari konsekuensinya adalah hati mereka tidak diberikan petunjuk dan argumen pembelaan karena tidak mengimaninya apa yang telah mereka dengarkan risalah Nabi dan kebenaran Allah-.

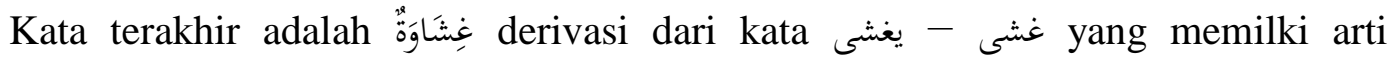
"menutupi" sinonim dari غطا - غيغطى. Pada tahapan ini lafaz tersebut menjadi penanda (ground) atau representamen. Petanda (objek) tingkatan pertama dari konteks ayat tersebut adalah menutupi mata mereka. Kemudian representasi pada tingkatan kedua adalah mereka menutup mata mereka dari ayat-ayat Allah dan wujud Allah -yang ditandai dengan adanya bumi, langit, dan diri-. Representasi itu dapat dipahami bahwa Allah menutup mata mereka dikarenakan mereka tidak melihat adanya Allah dari ayatayatNya, akibatnya mereka tidak akan mendapatkan petunjuk Allah untuk melihat hikmah dan pelajaran dari makhluk dan semua hal yan diciptakaanNya.

Sikap dan ciri-ciri di atas sewajarnya tidak boleh ada pada diri masyarakat modern, dengan adanya bukti ciptaan dan risalah Nabi dikemas dengan sedemikian rupa seharusnya menguatkan dan memantapkan hati, pikiran, pendengaran, dan penglihatan untuk bertauhid kepada-Nya. Supaya siksaan yang sebagaimana ditimpakan kepada orang kafir dan disifati dengan 'besar' tidak didapati oleh masyarkat modern.

\section{Kesimpulan}

Dengan melihat relasi-repsresentemen-interpretan, maka ciri-ciri orang kafir yaitu (1) tidak mempercai/tidak beriman terhadap sesuatu yang telah diturunkan oleh Allah al-Qur'an, Taurat, Zabur, dan Injil-; (2) tidak yakin adanya hari akhir; (3) tidak percaya pada hal yang gaib -seperti hari kebangkitan, surga, dan neraka-; (4) tidak melaksanakan salat -dengan menghinkannya-; (5) tidak mendistribusikan harta di jalan 
Allah atau tidak menunaikan hak dari harta tersebut; (6) hatinya tidak beriman; (7) pendengarannya tidak digunakan untuk mendengarkan risalah Nabi, bahkan condong menghina dan menginkari; (8) penglihatan mereka tidak ditujukan pada wujud Allah yang diwakili oleh ayat qouliyah ataupun kauniyah.

\section{Daftar Pustaka}

Mu'arrofah, Alifatul Qolbi. Representasi Masyarakat Pesisir: Analisis Semiotika dalam Novel Gadis Pesisir Karya Nunuk Y. Kusmiana. "Kajian Linguistik pada Karya Sastra”. Prosiding seminar Nasional Linguistiks dan Sastra (SEMANTIKS) 2019. http://jurnal.uns.ac.id/semantiks.

Hanafi, Wahyu. 'Semiotika Al-Qur'an: Representasi Makna Verba Reflektif Perilaku Manusia dalam Surat Al-Ma'un dan Bias Sosial Keaagamaan”. Jurnal Dialogia, Vol. 15, No. 1, (Juni 2017): 1-22.

Albar, Muhammad Wasith. "Analisis Semiotika Charles Sander Pierce Tentang Taktik Kehidupan Manusia: Dua Karya Kontemporer Putu Sutawijaya”. Jurnal Lensa Budaya, Vol. 13, No. 2 (2018): 123-136.

Fakhruddin Ar-Razi, Mafatih al-Ghaib, jilid. 2, cet. 3 (Beirut: Dar Ihya al-Turats al'Arabi, 1429 H). 